\title{
Immigration And The Labour Market In Castilla-La Mancha
}

\author{
Manuel Vargas-Vargas, Ph.D., University of Castilla-La Mancha, Spain \\ Juan-Antonio Mondéjar-Jiménez, Ph.D., University of Castilla-La Mancha, Spain \\ José Mondéjar-Jiménez, Ph.D., University of Castilla-La Mancha, Spain \\ María-Leticia Meseguer-Santamaría, University of Castilla-La Mancha, Spain
}

\begin{abstract}
In the last two decades it has growing the scientific interest in the socio-economic impacts of immigration on labour conditions of native workers. The studies show that these impacts are generally very weak and they are relatively concentrated in certain economic sectors. In the Spanish case, the studies concur with this assessment but found some differences when analyzing the increase occurred in the last ten years, due in part to the sectorial composition and the different initial share of immigrant workers. With this framework, the main aim of this paper is to analyze the impact of immigration on the employment in Castilla-La Mancha. Specifically, we study the general features of the incorporation of immigrant workers, their sectorial concentration and if there is a "replacement" effect over the native workers.
\end{abstract}

Keywords: Shift-Share, Labour Market, Immigration, Labour integration.

\section{INTRODUCTIÓN}

$\mathrm{n}$ the last 20 years the phenomenon of human migration has undergone great growth for many reasons, and the major demographic, social, economic and political effects of migratory flows have aroused an interest in their study on the part of social and political stakeholders, which has also led to academic interest in the subject.

In developed countries, the growing proportion of migrant population and the new characteristics of migratory flows have given rise to a thorough scholarly review of immigration's socioeconomic impact, as may be seen in Borjas (2003), Dustmann \& Glintz (2005) or Longhi, Nijkamp \& Poot (2006).

Given the statistical difficulties in directly investigating such impacts, the most widespread approach is to correlate wages or employment levels with the rate of immigration in various labour markets (normally regional) or sectors of activity. The general conclusion that seems to be drawn from empirical studies is that immigration has a slight impact on the employment rate for native workers and on wage levels, as shown in Carrasco, Jimeno \& Ortega (2008), which is reinforcing the agreement among specialists that labour markets use other means to adapt to and absorb the rise in supply. Even in more detailed studies the results are constant: in Borjas (2003) very moderate impacts are determined, where a 10\% rise in the number of migrant workers brings wages down by only 2 to $3 \%$; and, at EU level, Angrist \& Kugler (2003) show that such impacts are very moderate, finding differences between countries that are explained by different degrees of "flexibility" in their respective labour markets.

Within the general immigration process, increasing attention has been paid to illegal immigration, a phenomenon with various particularities and that has been the subject of political and social controversy in many countries. Due to such immigration's very nature, the difficulty of any quantitative treatment limits the possibilities for analysis. However, studies such as Djajic (1997), Hillman \& Weiss (1999), Venturini (1999) at international level or Ferri, Gómez-Plana \& Martín-Montaner (2001) in the Spanish case have agreed that the impact of such immigrants has been largely concentrated in just a few sectors, normally in which there was already a certain presence of migrant workers, and that this group shows little cross-sector mobility. 
In Spain, the studies conducted also agree as to the slight impact that immigration has had on the labour market. Studies such as Ferri, Gómez-Plana \& Marín-Montaner (2001), Amuedo-Dorantes \& De la Rica (2007), Carrasco, Jimeno \& Ortega (2008) or Muñoz, Carrera \& Antón (2009) analyze immigrants' labour market penetration and show that any negative effects are insignificant, underlining the lack of empirical support for the commonplace beliefs on this point. However, there seem to be signs of a certain degree of asymmetry in impact on regional labour markets, partly due to different levels of migratory flows and to the sectoral make-up in the various regions.

In this general framework, the goal of this study is to analyze the ingress of immigrants into the labour market of Castilla-La Mancha. On the basis of information contained in the Labour Force Survey (EPA) conducted by the Spanish National Statistical Institute (INE), a study is made of employment by sector distinguishing between Spanish and migrant workers between 1999 and 2007 (Vargas, Mondéjar \& Meseguer, 2008).

\section{THE IMMIGRANT LABOUR MARKET IN CASTILLA-LA MANCHA}

In the last 25 years, Spain has become a host country for a large flow of immigrants chiefly from Eastern Europe, Africa and Latin America, as shown by Amuedo-Dorantes \& De la Rica (2006). Castilla-La Mancha has not been impervious to this phenomenon. As we said, this sharp increase is commonly linked to a very wide range of socio-demographic issues and tensions, and in particular as regards the labour market. The commonplace beliefs as to a decrease in the number of jobs and in wages for native workers caused by immigrants, though unsupported by specialized literature, give rise to popular attitudes verging on, if not actually justifying, xenophobia. Moreover there is a need for employment policy to be adapted to this population's specific features, for its participation in the labour market is particularly important to its assimilation into society. These realities have aroused academic interest and given reason for an analysis of the immigrant population's participation in the labour market.

Table I: Spanish and foreign population in the last decade

\begin{tabular}{|c|c|c|c|c|c|c|c|c|c|}
\hline & \multicolumn{3}{|c|}{1999} & \multicolumn{3}{|c|}{2007} & \multicolumn{3}{|c|}{ Mean year-to-year rates } \\
\hline & Span. & Imm. & TOTAL & Span. & Imm. & TOTAL & Span. & Imm. & Total \\
\hline Agriculture & $66.178,53$ & 315,73 & $66.494,26$ & $48.884,04$ & $11.062,13$ & $59.946,17$ & $-3,72 \%$ & $55,98 \%$ & $-1,29 \%$ \\
\hline Industry & $122.251,98$ & 554,56 & $122.806,54$ & $131.888,59$ & $12.795,21$ & $144.683,79$ & $0,95 \%$ & $48,04 \%$ & $2,07 \%$ \\
\hline Industry (food, tex., lea., tim. \& pap.) & $63.067,84$ & 395,06 & $63.462,89$ & $56.188,90$ & $6.346,84$ & $62.535,73$ & $-1,43 \%$ & $41,49 \%$ & $-0,18 \%$ \\
\hline Industry (min., oil, chem., rub.) & $35.163,34$ & 64,35 & $35.227,69$ & $50.202,36$ & $5.593,92$ & $55.796,28$ & $4,55 \%$ & $74,74 \%$ & $5,92 \%$ \\
\hline Industry (mach., elec., trans, manu.) & $24.020,80$ & 95,16 & $24.115,96$ & $25.497,34$ & 854,45 & $26.351,78$ & $0,75 \%$ & $31,57 \%$ & $1,11 \%$ \\
\hline Construction & $81.538,73$ & 213,07 & $81.751,80$ & $117.940,74$ & $24.393,58$ & $142.334,32$ & $4,72 \%$ & $80,86 \%$ & $7,18 \%$ \\
\hline Services & $212.713,78$ & $1.287,32$ & $214.001,10$ & $285.520,13$ & $39.365,84$ & $324.885,96$ & $3,75 \%$ & $53,35 \%$ & $5,36 \%$ \\
\hline Services (comm. \& hotel/catering) & $123.729,18$ & 539,11 & $124.268,30$ & $142.458,29$ & $19.508,82$ & $161.967,11$ & $1,78 \%$ & $56,61 \%$ & $3,37 \%$ \\
\hline Services (transport) & $25.538,86$ & 22,84 & $25.561,70$ & $40.732,38$ & $2.412,61$ & $43.144,99$ & $6,01 \%$ & $79,05 \%$ & $6,76 \%$ \\
\hline Services (fin. interm. and real est.) & $34.234,97$ & 37,67 & $34.272,63$ & $67.513,33$ & $3.278,72$ & $70.792,05$ & $8,86 \%$ & $74,77 \%$ & $9,49 \%$ \\
\hline Services (others) & $29.210,77$ & 687,71 & $29.898,48$ & $34.816,14$ & $14.165,68$ & $48.981,82$ & $2,22 \%$ & $45,96 \%$ & $6,36 \%$ \\
\hline Public Admin, Edu \& Health & $102.556,78$ & 388,20 & $102.944,98$ & $167.339,05$ & $3.898,16$ & $171.237,21$ & $6,31 \%$ & $33,42 \%$ & $6,57 \%$ \\
\hline Total & $585.239,80$ & $2.758,88$ & $587.998,68$ & $751.572,54$ & $91.514,92$ & $843.087,46$ & $3,18 \%$ & $54,92 \%$ & $4,61 \%$ \\
\hline
\end{tabular}

Source: Labour Force Survey, National Statistical Institute

For Castilla-La Mancha, this involves a description of immigrants' ingress into the regional labour market in the period 1999-2007. The statistical information used is from the Labour Market Survey (EPA) conducted by the National Statistical Institute (INE); in particular this study addresses employment in various economic sectors in the populations of Spanish and foreign workers. Annual employment figures for Castilla-La Mancha in 1999 and 2007 are given in table I, along with the mean year-to-year rates.

The first circumstance that stands out is the strong average year-to-year rise in employment among immigrants, in total 17 times greater than that recorded among Spaniards and which in some sectors totals more than $5000 \%$. The number of "legal" labour market entrants was very great, rising from just $0.47 \%$ of total employment in 1999 to $10.85 \%$ eight years later.

In the trend in immigrant employment, no significant jump is apparent in the various quarters of 2005 or in early 2006 that might be attributable to the extraordinary regularization process that took place then in Spain, which 
seems to indicate that it did not involve the "legalization" of migrant workers employed in the underground economy. Given that the sectoral distribution is not comparable between the Spanish and migrant working populations, the trend in employment by economic sector was analyzed (Vargas, Mondéjar \& Meseguer, 2008).

\section{COMPARATIVE SECTORAL ANALYSIS OF EMPLOYMENT BY SECTOR AND NATIONALITY}

By applying the Shift-Share breakdown (Mayor, López \& Pérez, 2005) to the average annual number of workers in each economic sector in Castilla-La Mancha, we may consider what factors should be linked to the rise in working population between 1999 and 2007. As shown in table II, a comparison between the actual increase and the overall effect (OE) shows that, in aggregate, agriculture, industry and services grew below the average rate, while construction was rather more dynamic, as was, above all, the sector of non-market services (public administration, education and health), where the actual increase was nearly three times that linked to the OE. If we analyze the table as regards the population of Spanish workers, we see that the actual increases are always lower than the OE, due to lower growth in almost all sectors, and most notably, in relative terms, to less vigour in construction, services and agriculture. Among migrant workers the situation is inverted: here the actual growth in much higher than the $\mathrm{OE}$, reflecting this population's greater rate of ingress to employment, most notably, in relative terms, to the construction sector, in which the growth is more than 180 times the OE.

Table II: Increase in employment and overall effect

\begin{tabular}{||c|ccc|ccc||}
\hline & \multicolumn{3}{|c|}{ Increase } & \multicolumn{3}{c|}{ Overall effect } \\
& Spaniards & Immigrants & Total & Spaniards & Immigrants & Total \\
\hline Agriculture & $-17.294,49$ & $10.746,40$ & $-6.548,09$ & $41.632,73$ & 198,62 & $41.831,35$ \\
Industry & $9.636,61$ & $12.240,64$ & $21.877,25$ & $76.908,38$ & 348,87 & $77.257,25$ \\
Construction & $36.402,01$ & $24.180,51$ & $60.582,52$ & $51.295,79$ & 134,04 & $51.429,83$ \\
Services & $69.444,83$ & $38.078,52$ & $107.523,34$ & $133.817,65$ & 809,85 & $134.627,50$ \\
Public ad., edu. \& health & $182.963,35$ & $3.509,96$ & $186.473,31$ & $64.518,18$ & 244,21 & $64.762,40$ \\
Total & $281.152,30$ & $88.756,03$ & $369.908,33$ & $368.172,73$ & $1.735,60$ & $369.908,33$ \\
\hline
\end{tabular}

Source: Compiled by authors on the basis of Labour Force Survey data, INE

Table III: Net, structural and competitive effects (sectoral structure)

\begin{tabular}{||c|ccc|cc|cc||}
\hline & \multicolumn{3}{|c|}{ Net effect } & \multicolumn{2}{c|}{ Structural effect } & \multicolumn{2}{c|}{ Competitive effect } \\
& Spaniards & Immigrants & Total & Spaniards & Immigrants & Spaniards & Immigrant \\
\hline Agriculture & $-58.927,22$ & $10.547,78$ & $-48.379,44$ & $-48.149,72$ & $-229,72$ & $-10.777,49$ & $10.777,49$ \\
Industry & $-67.271,77$ & $11.891,77$ & $-55.380,00$ & $-55.129,92$ & $-250,08$ & $-12.141,85$ & $12.141,85$ \\
Construction & $-14.893,78$ & $24.046,47$ & $9.152,69$ & $9.128,84$ & 23,85 & $-24.022,62$ & $24.022,62$ \\
Services & $-64.372,82$ & $37.268,66$ & $-27.104,16$ & $-26.941,11$ & $-163,04$ & $-37.431,71$ & $37.431,71$ \\
Public ad., edu. \& health & $118.445,16$ & $3.265,75$ & $121.710,91$ & $121.251,94$ & 458,96 & $-2.806,78$ & $2.806,78$ \\
Total & $-87.020,43$ & $87.020,43$ & 0,00 & 0,00 & 0,00 & $-87.020,43$ & $87.020,43$ \\
\hline
\end{tabular}

Source: Compiled by authors on the basis of Labour Force Survey data, INE

The increases linked to factors specific to each sector are shown in table III, with both the net effect and a breakdown into structural effect (SE) and competitive effect (CE). For workers as a whole, the net effect is positive only in construction and non-market services, showing that the gap in growth relative to the overall rate was largely concentrated in the latter sector, at the expense of a lower rate in industry and agriculture.

This situation is similar to that obtained among Spanish workers. Both for all the sectors and for the first four, the net effect is negative, partially offset by non-market services. Within overall growth, the employment gap was concentrated in this single sector, which has become the great niche of employment in Castilla-La Mancha. This net effect (NE) is linked to the overall growth in the regional labour market. If we compare each case with the growth in its respective economic sector, we will get the structural effect and, from the differences, the competitive effect shown in table V. For Spanish workers, the CE is always negative, so employment growth is, in terms of rates, 
always lower than that recorded for immigrants. Regarding the SE, only in construction is it contrary to the NE, showing the sector's greater vigour.

Among migrant workers the situation is different. In this case the overall net effect is positive, as are all the sectoral effects. Though in absolute terms migrant employment exceeds Spanish employment only in agriculture and industry, in percentage terms it is always greater, with a notably large margin in services and construction and a more moderate one in non-market services. With these results, the pattern in the flow of migrant workers is different from that for Spanish ones. On one hand, their ingress to the agricultural sector mitigated the sector's loss of employment, which would have been nearly three times greater without them. On the other, their labour market penetration was chiefly concentrated in construction and services, i.e. sectors with a greater need for unskilled labour, and driving forces of regional GDP growth. The net effect may also be broken down in comparison with the average growth in each population. In this case the structural effect will quantify the difference in sectoral growth due to the different composition of Spanish and foreign workers, whereas the competitive effect will show each sector's comparative appeal for each population; these data are set out in table IV.

Table IV: Net, structural and competitive effects (sectoral structure)

\begin{tabular}{||c|ccc|cc|cc||}
\hline & \multicolumn{3}{|c|}{ Net effect } & \multicolumn{2}{c|}{ Structural effect } & \multicolumn{2}{c|}{ Competitive effect } \\
& Spaniards & Immigrants & Total & Spaniards & Immigrants & Spaniards & Immigrants \\
\hline Agriculture & $-58.927,22$ & $10.547,78$ & $-48.379,44$ & $-9.840,21$ & $9.958,73$ & $-49.087,01$ & 589,05 \\
Industry & $-67.271,77$ & $11.891,77$ & $-55.380,00$ & $-18.177,88$ & $17.491,95$ & $-49.093,89$ & $-5.600,18$ \\
Construction & $-14.893,78$ & $24.046,47$ & $9.152,69$ & $-12.124,15$ & $6.720,61$ & $-2.769,63$ & $17.325,86$ \\
Services & $-64.372,82$ & $37.268,66$ & $-27.104,16$ & $-31.628,82$ & $40.604,62$ & $-32.744,00$ & $-3.335,95$ \\
Public ad., edu. \& health & $118.445,16$ & $3.265,75$ & $121.710,91$ & $-15.249,36$ & $12.244,53$ & $133.694,53$ & $-8.978,78$ \\
Total & $-87.020,43$ & $87.020,43$ & 0,00 & $-87.020,43$ & $87.020,43$ & 0,00 & 0,00 \\
\hline
\end{tabular}

Source: Compiled by authors on the basis of Labour Force Survey data, INE

The competitive effects in this case bear out the above remarks. For Spanish workers, only the non-market service sector shows a positive value, due to its greater labour market appeal. In the case of immigrants, the sector with the biggest growth gaps is construction, followed at a distance by agriculture. Thus a degree of "specialization" in employment growth among Spaniards appears in the non-market tertiary sector, while immigrant employment growth is "specialized" in construction. This fact again points to a complementarity between the two populations, covering the labour needs of the various sectors, rather than to any "replacement" or "stealing" of jobs by migrant workers.

In turn, to separate the effects of the different initial proportions of workers in each sector, we may break down the competitive effect as net and locational, as shown in table V. For the population of Spanish workers almost all of the competitive effect is net, as the locational effect is very slight, due to this group's near-zero statistical association with the economic sectors. But in the immigrant population, the locational effect in construction is important, and almost doubles the net competitive effect if the effects of the different initial proportions of workers are not separated.

Table V: Net and locational competitive effects (by nationality)

\begin{tabular}{|c|cc|cc|cc||}
\hline & \multicolumn{2}{|c|}{ Competitive effect } & \multicolumn{2}{c|}{ Net competitive effect } & \multicolumn{2}{c|}{ Locational effect } \\
& Spaniards & Immigrants & Spaniards & Immigrants & Spaniards & Immigrants \\
\hline Agriculture & $-49.087,01$ & 589,05 & $-49.089,78$ & 582,07 & 2,77 & 6,98 \\
Industry & $-49.093,89$ & $-5.600,18$ & $-49.085,20$ & $-5.818,76$ & $-8,69$ & 218,58 \\
Construction & $-2.769,63$ & $17.325,86$ & $-2.763,84$ & $31.190,96$ & $-5,79$ & $-13.865,09$ \\
Services & $-32.744,00$ & $-3.335,95$ & $-32.787,60$ & $-2.601,99$ & 43,60 & $-733,96$ \\
Public ad., education. \& health & $133.694,53$ & $-8.978,78$ & $133.570,92$ & $-11.171,86$ & 123,61 & $2.193,08$ \\
Total & 0,00 & 0,00 & 0,00 & 0,00 & 0,00 & 0,00 \\
\hline
\end{tabular}

Source: Compiled by authors on the basis of Labour Force Survey data, INE 
To consider the locational effect's behaviour more closely, if for each population of workers we group the sectors according to whether they show positive or negative location and specialization effects, we may obtain a twin-input table similar to that proposed in Alavi \& Yasin (2000). In the sectors with a positive locational effect for Spanish workers, only in public administration, education and health do we find above-average growth (advantage + ) with more workers than the pre-existing scaled numbers (specialization -). Employment growth in these sectors tended to perpetuate the comparative proportions existing in 1999. The negative locational effect in the industry and construction sectors, on the other hand, is due to sectoral growth below average for the group in the sectors in which there were more workers than would be expected with independence. In the case of immigrants, the positive locational effect is due, in agriculture, to greater relative growth in a sector with a greater initial presence of foreign workers, while in industry and public administration, education and health it is caused by lower relative growth in sectors where there were fewer immigrants than to be expected if there had been independence between sectors and nationality. The service sector, in which the specialization was positive, shows a negative locational advantage, as the sectoral rate of growth for immigrant employment was less than that recorded for the group as a whole. Finally, the construction sector shows a positive locational advantage along with a negative specialization.

Table VI: Specialization as opposed to locational advantage (by nationality)

\begin{tabular}{|c|c|c|c|}
\hline \multirow{2}{*}{\multicolumn{2}{|c|}{$\begin{array}{c}\text { Spaniards } \\
\text { Immigrants }\end{array}$}} & \multicolumn{2}{|c|}{ Locational advantage } \\
\hline & & Advantage (+) & Disadvantage (-) \\
\hline \multirow{2}{*}{ 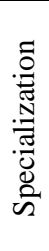 } & $\begin{array}{c}\text { Specialization } \\
(+)\end{array}$ & $\begin{array}{l}\text { Public ad. } \\
\text { Agriculture }\end{array}$ & $\begin{array}{l}\text { Industry } \\
\text { Construction } \\
\text { Services }\end{array}$ \\
\hline & $\begin{array}{c}\text { Non- } \\
\text { specialization } \\
(-)\end{array}$ & Construction & $\begin{array}{l}\text { Agriculture } \\
\text { Services } \\
\text { Industry } \\
\text { Public ad. }\end{array}$ \\
\hline
\end{tabular}

Source: Compiled by authors

Finally, as shown by the above remarks, there seems to be no statistical independence between workers in each sector and nationality. To measure the association between the two attributes in Castilla-La Mancha, by aggregating the squared quotients between the specialization in each combination and scaled employment, we obtain a value of $\chi 2$ for independence contrasts.

Table VII: Association between sector and nationality

\begin{tabular}{||c|c|cc||}
\hline & \multicolumn{3}{|c|}{$\begin{array}{c}\text { Association between sector and nationality } \\
\text { Immigrants }\end{array}$} \\
\hline Agriculture & Spaniards & $4.969,98$ & $5.494,94$ \\
Industry & 524,97 & 76,36 & 84,42 \\
Construction & 8,07 & $8.570,50$ & $9.475,78$ \\
Services & 905,28 & $2.435,04$ & $2.692,25$ \\
Public ad., edu. \& health & 257,21 & $20.403,21$ & $22.558,35$ \\
Total & $2.155,14$ & $36.455,08$ & $40.305,75$ \\
\hline
\end{tabular}

Source: Compiled by authors on the basis of Labour Force Survey data, INE

For average employment levels in 2007, the aggregate value of $\chi^{2}$ is 40305.99 , and so Cramer's V is 0.6636 , indicating a moderate association between the two attributes. Larger contributions to $\chi 2$ would indicate stronger associations, which turn out to be those of the immigrant population. The population of Spanish workers shows only a moderate association with the sector of public administration, education and health. 


\section{CONCLUSIONS}

This study made a preliminary appraisal of labour market penetration by immigrants in Castilla-La Mancha, and of the possible effects that this may have had on employment for native workers. On the basis of data taken from the Labour Force Survey we sought to extract quantitative information on how this penetration has taken place, in what sectors and whether this has been at the expense of a fall in Spanish employment.

First we should note that the sharp increase in immigrant employment is similar, in terms of rates, to the increase in the registered resident foreign population. This impression is corroborated by the positive correlation between the two series of workers, more in keeping with the covering of unmet demand than with any "competition" for jobs.

This general trend does not apply in the primary sector. In agriculture, the decrease in Spanish employment has been partially mitigated by a penetration by immigrants, who have taken vacant jobs at the wages offered. In other sectors the growth levels experienced are always positive for both populations, though with distinguishing features. On one hand, Spanish workers have shown uneven sectoral growth, with a large concentration in the nonmarket service sector (public administration, education and health), the only sector in which they have a comparative advantage over the growth recorded among immigrants. On the other hand, the growth in foreign employment has been proportionally more significant in construction and services, as shown by the more moderate net competitive effect in the industrial sector.

Accordingly it seems that the labour market in Castilla-La Mancha has assimilated the growth in the immigrant labour force by means of covering its growing needs and, to a partial extent, assigning Spanish workers more to public services and immigrants to agriculture, construction and services. In line with the empirical results set out in the specialized bibliography, this reality does not support the popular perception that immigration has taken jobs away from Spanish workers, as employment growth has been positive and has absorbed the increase in the labour force, as shown by the progressive fall in the unemployment rate. Another issue, not addressed in this study, is the impact that this may have had on wage levels, in which any rises might have been limited by the growing size of a group with fewer economic means (Vargas, Mondéjar \& Meseguer, 2008).

\section{AUTHOR INFORMATION}

Manuel Vargas-Vargas: PhD in Economics by University of Castilla-La Mancha and Degree in Mathematics by University of Granada. Associate Professor in Statistics at Statistics Department. Faculty of Economics and Business Administration of Albacete. University of Castilla-La Mancha (Spain). Research Interest: State-space models, regional analysis, educational and tourism.

Juan-Antonio Mondéjar-Jiménez: $\mathrm{PhD}$ and Degree in Business Administration by University of Castilla-La Mancha. Degree in Advanced Studies in Marketing at the same university. Assistant Professor in Marketing at Business Administration Department. Faculty of Social Sciences of Cuenca. University of Castilla-La Mancha (Spain). Research Interest: E-learning, consumer behavior, price perception and tourism marketing.

José Mondéjar-Jiménez: European PhD in Economics and Degree in Business Administration by University of Castilla-La Mancha. Degree in Advanced Studies in Statistics at the same university. Assistant Professor in Statistics at Statistics Department. Faculty of Social Sciences of Cuenca. University of Castilla-La Mancha (Spain). Research Interest: State-space models, regional analysis, educational and tourism.

María-Leticia Meseguer-Santamaría: Degree in Business Administration by University of Castilla-La Mancha. Assistant Professor in Statistics at Statistics Department. Faculty of Economics and Business Administration of Albacete. University of Castilla-La Mancha (Spain). Research Interest: State-space models, regional analysis, educational and tourism. 


\section{REFERENCES}

1. Alavi, J. \& Yasin, M. M. (2000). "A Systematic Approach to Tourism Policy”, Journal of Business Research, 48, 147-156.

2. Amuedo-Dorantes, C. \& De la Rica, S. (2007). "Labor Market Assimilation of Recent Immigrants in Spain”, British Journal of Industrial Relations, 45 (2), 257-284.

3. Angrist, J. \& Kugler, A. (2003). "Productive or counter-productive: Labour Market Institutions and the Effect of Immigration on EU natives". The Economic Journal, 113 (488), 302-331.

4. Borjas, G. (2003). "The labor demand curve is downward sloping: reexamining the impact of immigration on the labor market", Quarterly Journal of Economics, 118 (4), 1335-1378.

5. Carrasco, R.; Jimeno, J. F. \& Ortega, A. C. (2008). "The effect of immigration on the labor market performance of native-born workers: some evidence for Spain”, Journal of Population Economics, 21, 627648.

6. Djajic, S. (1997). "Illegal Immigration and Resource Allocation," International Economic Review, 38 (1), 97-117.

7. Dustmann, C. \& Glitz, A. (2005). Immigration, Jobs and Wages: Theory, Evidence and Opinion. Londres, Centre for Economic Policy Research.

8. Ferri, J.; Gómez-Plana, A. G. \& Martín-Montaner, J. (2002). "International Immigration and Mobility Across Sectors: An Exploration of Alternative Scenarios for Spain”. Estudios sobre Economía Española, 124. FEDEA.

9. Hillman, A. L. \& Weiss, A. (1999). "A theory of permissible illegal immigration", European Journal of Political Economy, 15 (4), 585-604.

10. Longhi, S.; Nijkam, P. \& Poot, J. (2006). The Impact of Immigration on the Employment of Natives in Regional Labour Markets: A Meta-Analysis. ISER Working Paper 2006-10. Colchester, University of Essex.

11. Mayor, M.; López, A. J. \& Pérez, R. (2005). “Escenarios de empleo regional. Una propuesta basada en análisis shift-share", Estudios de economía aplicada, 23 (3), 863-887.

12. Muñoz, R.; Carrera, M. \& Antón, J. I. (2009). From Guests to Hosts: A First Whole Picture of ImmigrantNative Wage Differentials in Spain. MPRA Paper $\mathrm{n}^{\circ} 13928$.

13. Vargas, M.; Mondéjar, J. \& Meseguer, M. L. (2008). "Inmigración y mercado laboral en Castilla-La Mancha". SPCS. Documento de trabajo Facultad de Ciencias Sociales, 4.

14. Venturini, A. (1999). "Do immigrants working illegally reduce the natives' legal employment? Evidence from Italy", Journal of Population Economics, 12 (1), 135-154. 
NOTES 